\title{
Effect of Water Load, Saline Load and Lipton Tea on Urine Output and Urine Ph in Young Healthy Male and Female Human Subjects
}

\author{
Blessing Omolaso ${ }^{\mathrm{a}}$, Sule Uredo'ojo ${ }^{\mathrm{a}}$, Adeniran Akinola ${ }^{\mathrm{c}}$, Dr. Olutunde \\ Adegbite $^{\mathrm{a}}$ and Dr Francis Oluwole ${ }^{\mathrm{b}}$ \\ ${ }^{a}$ Department of Physiology, Bingham University, New Karu,Nasarawa State Nigeria \\ ${ }^{b}$ Department of Physiology, University of Ibadan,Ibadan,Nigeria \\ c.Department of Physiology, Igbinedon University, Okada,Edo State Nigeria \\ Corresponding Author's name and address: Blessing O. Omolaso \\ Department of Physiology, Bingham University, P.M.B 005, New Karu, Nasarawa State, Nigeria
}

\begin{abstract}
The study was aimed at comparing the diuretic effect of saline load, water load and Lipton tea in between healthy male and female undergraduate medical students (18-26yrs). They were randomly grouped into five groups having both male and female subjects : control(A),water(B), normal saline(C), Hypertonic saline, $1 \%(D)$, Lipton tea $(E)$. The day before the experiment, instructions were given; the experimental groups drank their solution $12 \mathrm{ml} / \mathrm{kg}$ body weight then the urine output was measured at 30mins interval. Paired $t$-test was used to analyse result between male and female intra group difference in urine output and $\mathrm{pH}$ with significant level having $p$ value $\leq 0.05$. The data are presented as mean \pm SEM. In water group at 30mins showed

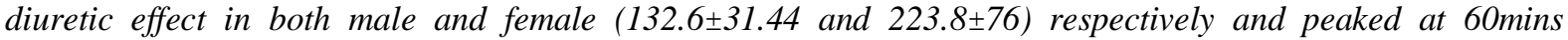
(202.4 \pm 38.96 and $304 \pm 36.78)$ in male and female. Lipton tea also showed diuretic effect which started in the females at 30mins $(68.2 \pm 8.92)$ while it started at 60 mins $(185.6 \pm 34.24)$ in the males.

It is therefore concluded that male and female subjects have same response to volume loading, however they were little variations in their pattern of response to this volume loading.
\end{abstract}

Keywords: Urine output, duiresis, volume loading

\section{Introduction}

Balance of water and electrolyte is an important homeostatic function of the kidneys. Their excretion is dependent on various factors which include state of hydration and plasma osmolarity (Paudel and Karma, 2003). Volume load such as water, normal saline and hypertonic solution are used in laboratory experiment for undergraduate medical students to appreciate the homeostatic function of the kidney. We decided to add lipton tea to the list. Lipton tea is widely consumed in this part of the world as part of meal or just as refreshment.

While there are reports establishing the effects of this volume loads on diuresis (Paudel and Kumar,2003; Udokang and Akpogomeh, 2005), there are few reports comparing gender difference of these effects.

This work was aimed at ascertaining any gender difference of the effects of these volume loads on diuresis and $\mathrm{pH}$ of the urine in young adult human

\section{Materials And Methods}

The experiment was carried out on 48 Medical undergraduate students of Bingham University Students Karu, Nasarawa State Nigeria, 24 male and female subjects each. The subjects recruited were given certain instructions before the day of the experiment;

I. $\quad$ Last meal should be at least 6 hours before the experiment

I. No strenuous exercise before the experiment

II. Not expected to be heavy drinkers or smokers

On the day of the experiment the subjects were given a light meal as breakfast. The subjects were made to void their bladder after which they were shared into five groups (A, B, C, D, E) based on the fluid to be taken. Group A; control, group B; water , group C; normal saline solution, group D; $1 \%$ hypertonic saline solution and group E; lipton Tea

The fluids were taken $12 \mathrm{ml}$ per body weight and their urine was collected for $150 \mathrm{mins}$ at $30 \mathrm{mins}$ intervals. The volume of the urine and $\mathrm{pH}$ was determined

\section{Statiscal Analysis}

The mean and SEM was calculated and then subjected to the paired student t-test for test of significance at $\mathrm{p}<0.05$ 


\section{Results}

TABLE 1: Effect of volume loading on Urine output in male and female human subjects and showing

Mean value \pm SEM and significance level betreen male and female

\begin{tabular}{|c|c|c|c|c|c|c|c|c|c|c|c|}
\hline \multirow[b]{2}{*}{ Duration } & \multirow[b]{2}{*}{ Sex } & & & & & GROUPS & & & & & \\
\hline & & $A($ control $)$ & & $B$ (water) & & $\mathrm{C}(0.9 \%$ saline $)$ & & $\mathrm{D}(1 \%$ saline $)$ & & E(Liptontea) & \\
\hline $30 \mathrm{mins}$ & $\mathrm{M}$ & $37.8 \pm 8.01$ & \multirow[b]{2}{*}{ ns } & $132.6 \pm 31.44$ & \multirow[b]{2}{*}{ ns } & $35.6 \pm 3.73$ & \multirow[t]{2}{*}{ ns } & $40.00=11.61$ & \multirow[b]{2}{*}{$*$} & $29.7 \pm 6.36$ & \\
\hline & F & $24.75=3.12$ & & $223.8=23.76$ & & $45.2 \pm 7.95$ & & $131.4=30.4$ & & $68.2 \pm 8.92$ & ${ }^{*}$ \\
\hline \multirow[t]{2}{*}{$60 \operatorname{mins}$} & $\mathrm{M}$ & $12.3=1.03$ & \multirow{2}{*}{ * } & $202.4=38.97$ & \multirow[t]{2}{*}{ ns } & $20.2 \pm 4.74$ & \multirow[t]{2}{*}{ ns } & $73.0=33.13$ & \multirow[t]{2}{*}{$\mathrm{ns}$} & $185.6=34.24$ & S \\
\hline & $\mathrm{F}$ & $18.5=1.26$ & & $304 \pm 36.78$ & & $25.4 \pm 4.95$ & & $96.0=34.5$ & & $291.0=45.54$ & \\
\hline \multirow[t]{2}{*}{$90 \operatorname{mins}$} & $\mathrm{M}$ & $16.25=1.93$ & \multirow[t]{2}{*}{ ns } & $108.6=23.93$ & \multirow[t]{2}{*}{ ns } & $27.1=1.80$ & \multirow[t]{2}{*}{ ns } & $38.4 \pm 9.00$ & \multirow[t]{2}{*}{ ns } & $210.8=31.97$ & \\
\hline & F & $14.75=1.89$ & & $196.0=36.78$ & & $22.0 \pm 4.97$ & & $65.8=18.17$ & & $109.2=7.65$ & \\
\hline \multirow{2}{*}{$120 \mathrm{mins}$} & M & $15.75=2.18$ & \multirow[t]{2}{*}{ ns } & $49.20=10.93$ & \multirow[t]{2}{*}{ ns } & $33.6 \pm 3.85$ & ns & $20.6 \pm 2.38$ & \multirow[t]{2}{*}{ ns } & $93.4=15.63$ & ns \\
\hline & $\mathrm{F}$ & $15.5 \pm 3.60$ & & $48.2 \pm 14.25$ & & $23.4=5.41$ & & $50.2=16.88$ & & $113.0=5.38$ & \\
\hline \multirow[t]{2}{*}{$150 \mathrm{mins}$} & $\mathrm{M}$ & $12.75=2.18$ & \multirow[t]{2}{*}{ ns } & $49.20=10.93$ & \multirow[t]{2}{*}{ ns } & $33.6 \pm 3.85$ & \multirow{2}{*}{ * } & $20.6=2.38$ & \multirow[t]{2}{*}{ ns } & $93.4=15.63$ & \\
\hline & $\mathrm{F}$ & $12.75=1.25$ & & $16.8=2.63$ & & $17.0=2.00$ & & $20.4=2.54$ & & $24.4 \pm 4.95$ & \\
\hline \multirow[t]{2}{*}{ TUO } & $\mathrm{M}$ & $94.25=13.71$ & \multirow{2}{*}{ ns } & $519.56=56.96$ & \multirow[t]{2}{*}{ ns } & $145.0 \pm 3.53$ & \multirow[t]{2}{*}{ ns } & $197.0=42.7$ & \multirow[t]{2}{*}{ ns } & $574.4=24.19$ & ns \\
\hline & F & $81.5=11.75$ & & $768.8 \pm 79.15$ & & $133.0=12.78$ & & $398.2=110.09$ & & $6058=51.18$ & \\
\hline
\end{tabular}

TU0=Total urine output, $\mathrm{S}=$ significance level, $\mathrm{M}=\mathrm{male}, \mathrm{F}=$ female, $\mathrm{ns}=$ not significant ${ }^{*}=$ significant where $\mathrm{P}$ value $[0.05$ is significant

Table 2 Effect of volume loading on urine $\mathrm{p}^{\mathrm{H}}$ in male and female human subjects showing mean value \pm SEM and significance level between male and female subjects

\begin{tabular}{|c|c|c|c|c|c|c|c|c|c|c|c|}
\hline & & & & & & GROUPS & & & & & \\
\hline Duration & $\operatorname{sex}$ & $A($ control) & & $B$ (water) & & $\mathrm{C}(0.9 \%$ saline $)$ & & $\mathrm{D}$ (1\%saline) & & $E($ LintonTea $)$ & \\
\hline \multirow[t]{2}{*}{$30 \mathrm{mins}$} & $\mathrm{M}$ & $7.25 \pm 0.14$ & \multirow{2}{*}{ ns } & $7.20=0.20$ & \multirow{2}{*}{ ns } & $5.97 \pm 0.32$ & \multirow{2}{*}{ ns } & $5.76 \pm 0.30$ & \multirow{2}{*}{$*$} & $7.10=0.19$ & \multirow{2}{*}{$\mathrm{ns}$} \\
\hline & $\mathrm{F}$ & $7.13=0.13$ & & $6.70=0.12$ & & $6.40=0.25$ & & $6.60=0.10$ & & $6.90=0.10$ & \\
\hline \multirow[t]{2}{*}{$60 \mathrm{mins}$} & $\mathrm{M}$ & $7.13=0.13$ & \multirow{2}{*}{ ns } & $7.20=0.20$ & & $6.92=0.56$ & \multirow{2}{*}{$\mathrm{ns}$} & $5.80=0.30$ & \multirow{2}{*}{$\mathrm{ns}$} & $7.00=0.16$ & \multirow{2}{*}{$\mathrm{ns}$} \\
\hline & $\mathrm{F}$ & $7.13=0.13$ & & $6.70=0.12$ & ns & $6.47 \pm 0.45$ & & $6.90=0.19$ & & $6.80=0.20$ & \\
\hline \multirow[t]{2}{*}{$90 \mathrm{mins}$} & $\mathrm{M}$ & $7.00=0.00$ & \multirow{2}{*}{ ns } & $7.00=0.22$ & \multirow{2}{*}{ ns } & $6.22=0.48$ & \multirow{2}{*}{ ns } & $5.62=0.36$ & \multirow[b]{2}{*}{ ns } & $6.90=0.16$ & \multirow[b]{2}{*}{ ns } \\
\hline & F & $7.13=0.13$ & & $6.70=0.12$ & & $6.33=0.43$ & & $6.80=0.12$ & & $6.70=0.12$ & \\
\hline \multirow[t]{2}{*}{$120 \mathrm{mins}$} & $\mathrm{M}$ & $\begin{array}{l}\text { Not } \\
\text { comparable }\end{array}$ & & $7.00=0.16$ & \multirow[b]{2}{*}{ ns } & $6.11=0.35$ & & $5.62=0.38$ & \multirow[b]{2}{*}{ ns } & $7.00=0.22$ & \multirow[b]{2}{*}{ ns } \\
\hline & $\mathrm{F}$ & $\begin{array}{l}\text { Not } \\
\text { comparable }\end{array}$ & & $6.70=0.12$ & & $6.27 \pm 0.37$ & ns & $6.60=0.10$ & & $6.60=0.10$ & \\
\hline \multirow[t]{2}{*}{$150 \mathrm{mins}$} & $\mathrm{M}$ & $\begin{array}{l}\text { Not } \\
\text { comparable }\end{array}$ & & $6.90=0.19$ & \multirow[b]{2}{*}{ ns } & $6.02=0.41$ & \multirow[b]{2}{*}{ ns } & $5.66 \pm 0.35$ & \multirow[b]{2}{*}{ ns } & $6.90=0.24$ & \multirow[b]{2}{*}{$\mathrm{ns}$} \\
\hline & $\mathrm{F}$ & $\begin{array}{l}\text { Not } \\
\text { comparable }\end{array}$ & & $6.60=0.10$ & & $6.12=0.38$ & & $6.70=0.12$ & & $6.80=0.20$ & \\
\hline
\end{tabular}

$S=$ significance level, $M=$ male, $F=$ female, $n s=$ not significant $*=$ significant $\quad$ where $P$ value $\square 0.05$ is significant 


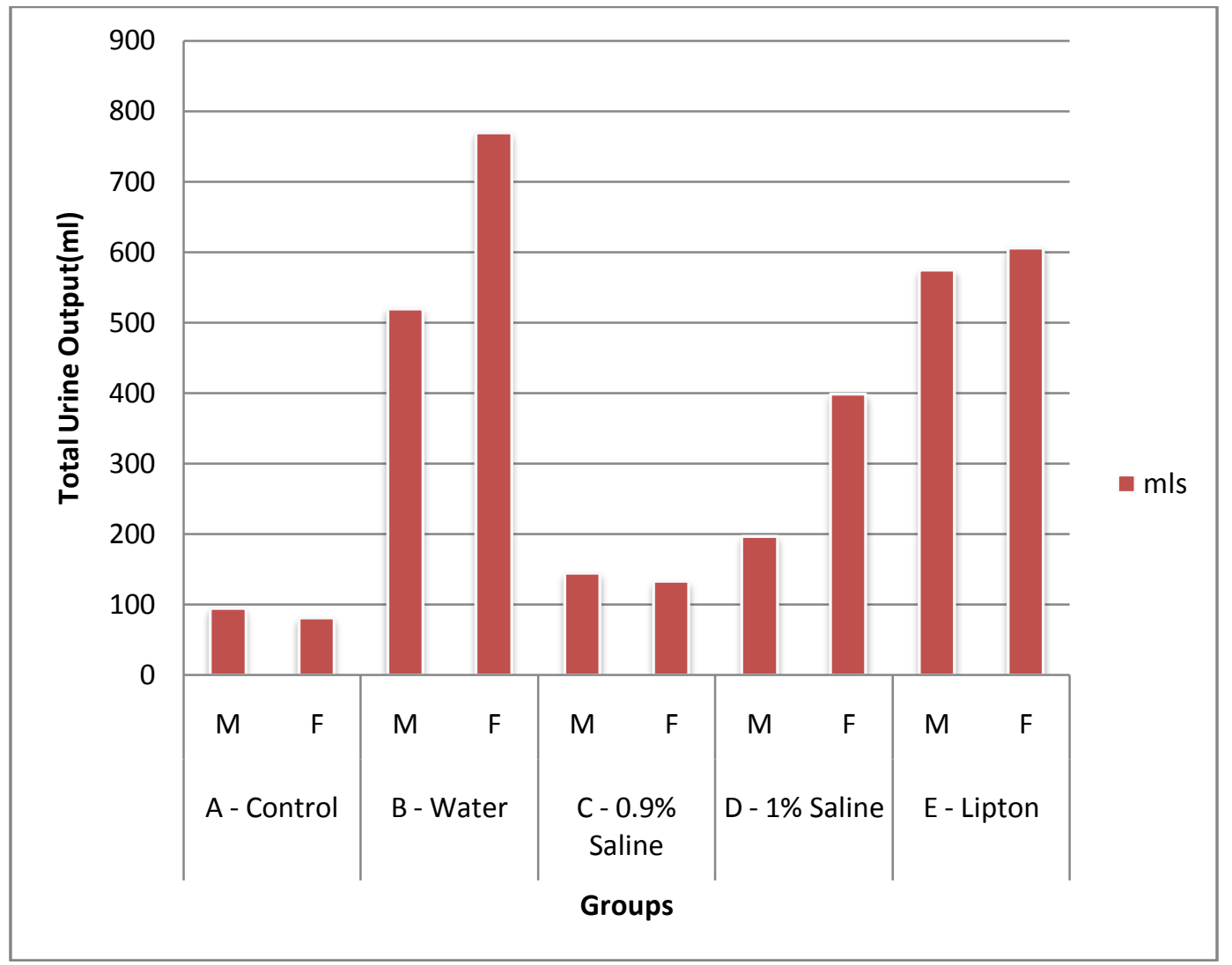

. Fig 1 Graph showing effect of volume loading on total urine output in both male and female subjects

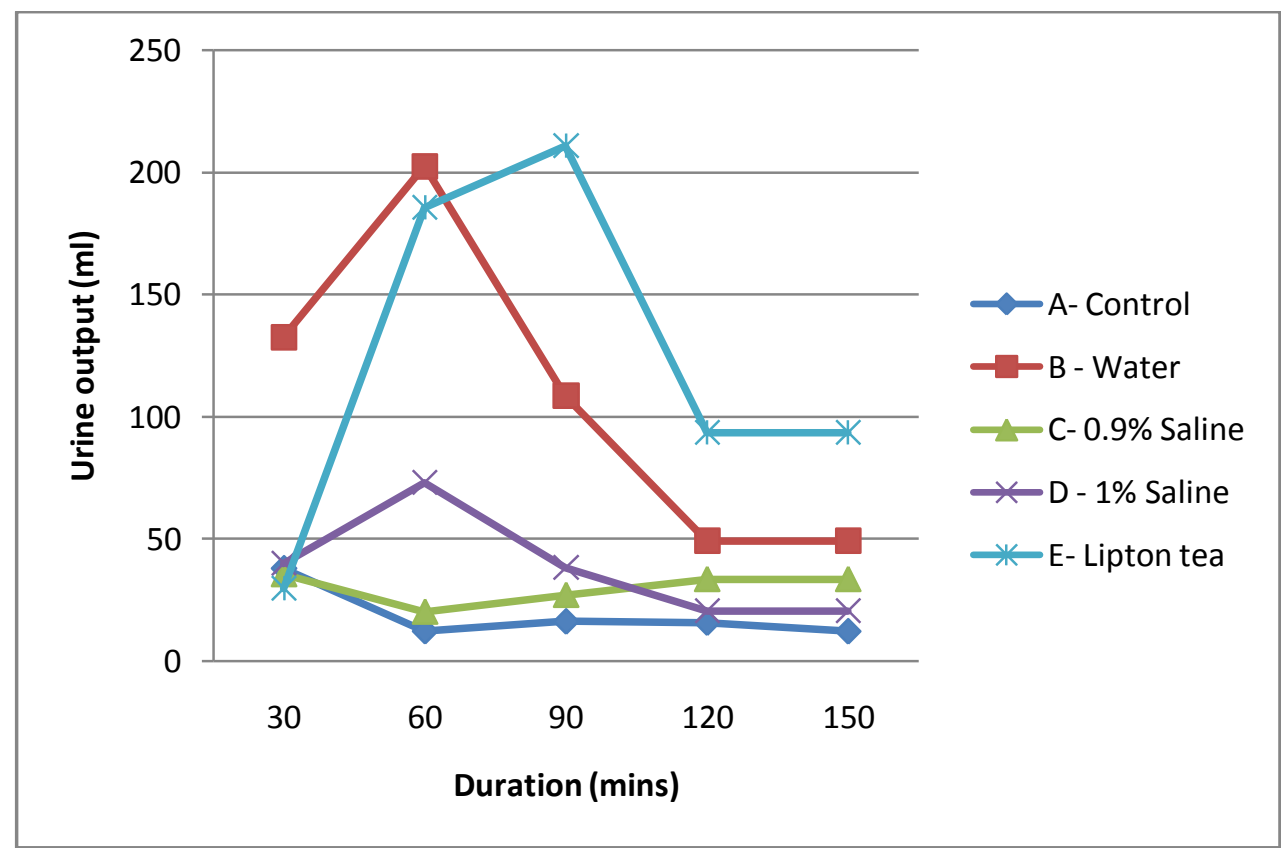

Fig 2 Graph showing effect of volume loading on urine output in male subjects. 


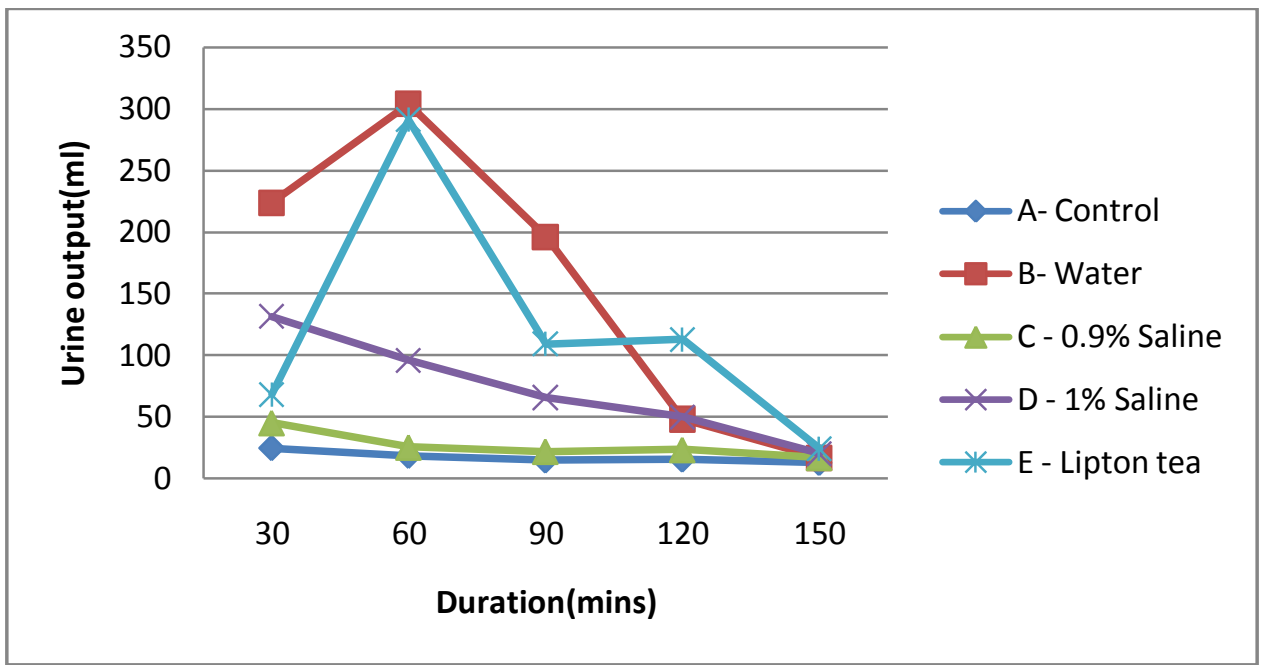

Fig 3Graph showing effect of volume loading on urine output in female subjects.

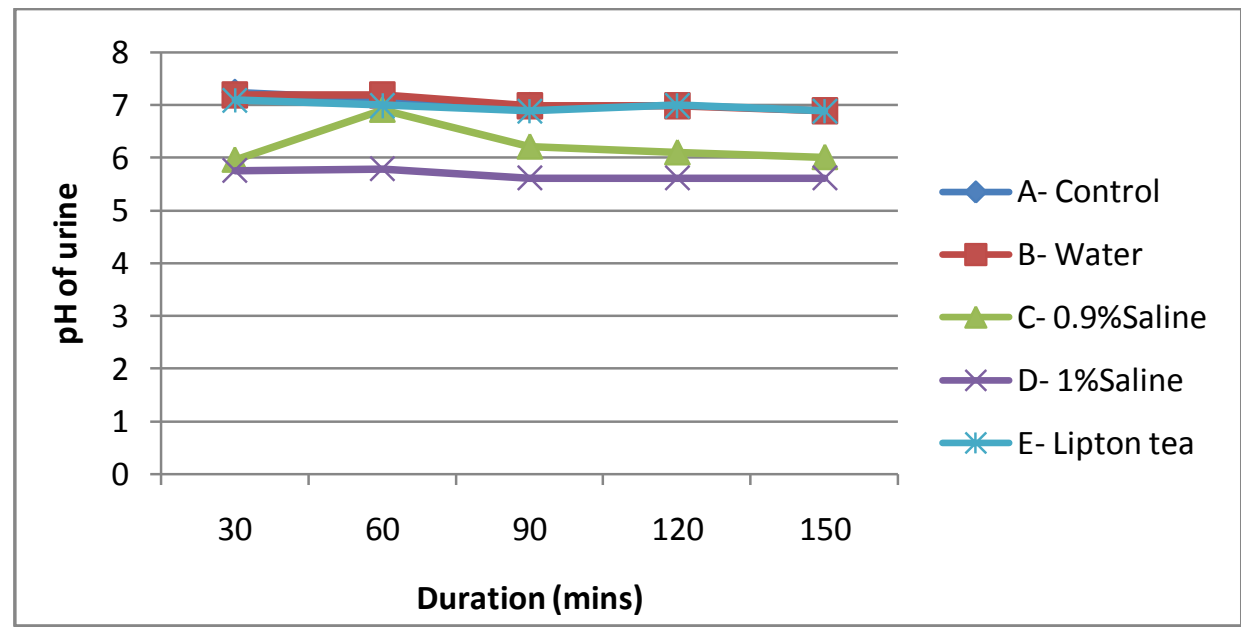

Fig 4 Graph showing effect of loading on urine $\mathrm{pH}$ in male subjects

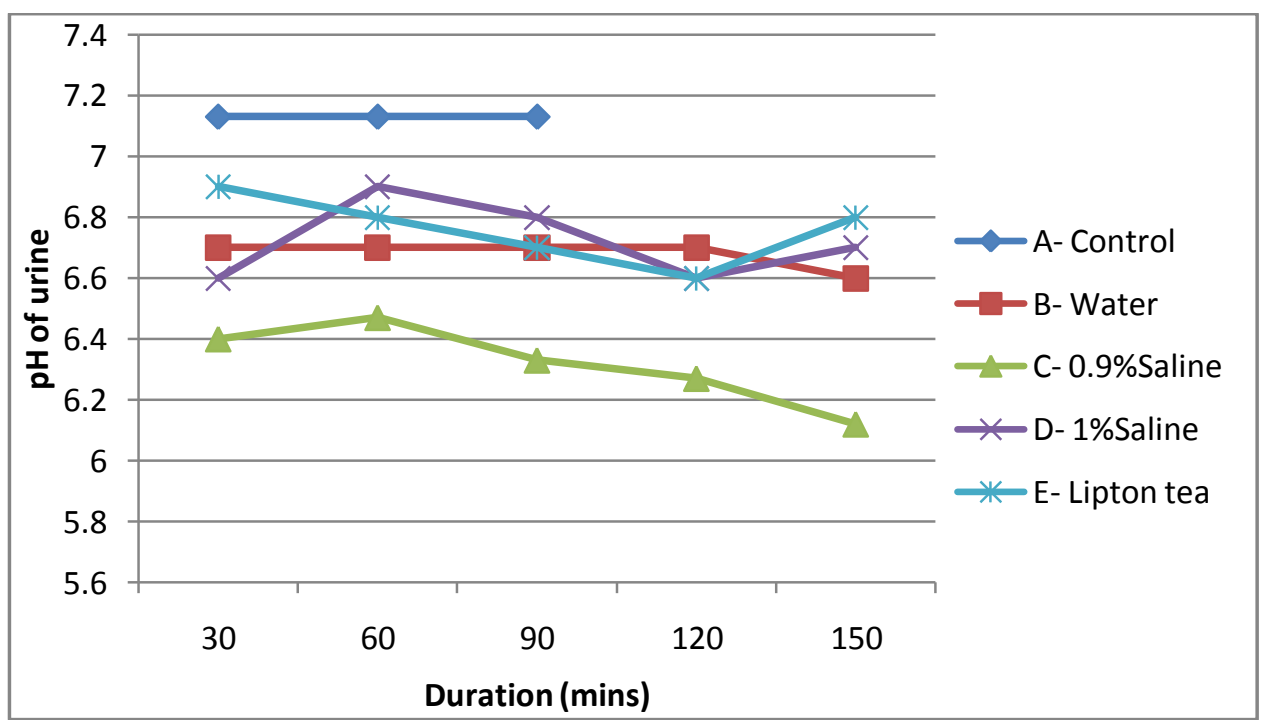

Fig.5 Graph showing Effect of loading on Urine pH in female subjects 


\section{Discussion}

In the present results, Normal Saline has no significant effect on diuresis when compared with control values in both male and female. This finding is consistent with previous work that report normal saline as weak stimuli of diuresis (Paudel and Kumer, 2003; Udokang and Akpogomeh, 2005).

The $1 \%$ Saline however showed tendency of increasing urine output, observed at 30mins in female and $60 \mathrm{mins}$ in male. This is not clear with the knowledge that saline load increases the osmolality of body fluid thus activating Antiduiretic hormone secretion and increased absorption of water thus decreasing urine output. Increase in urine output is lpossible with hypertonic sodium chloride loading with sufficient ECF expansion (Paudel and Kumer, 2003; Poujeol, 1976) ECF expansion was however not determined in this experiment.

Water (Group B) showed diuretic effect which started at 30mins and at its peak at 60mins after which it declines in both and male and female human subjects. (fig 2,3). This finding is in accordance to a similar work by Paudel and Kumer (2003) where the diuretic effect of water started at 60mins and maximal effect at 90mins. The diuretic effect of water is due to the increased Extracellular volume it creates leading to decrease in secretion of ADH and thus the increase in urine volume or output. (Guyton, 2006; Udokang and Akpogomeh, 2005)

Lipton tea (Group E) on the other hand showed a diuretic effect which started at 30min and peaked at $60 \mathrm{mins}$ in female human subjects. In males subjects it started at $60 \mathrm{mins}$ and peaked at $90 \mathrm{mins}$ after which it declined in both male and female human subjects (fig 2,3)

The diuretic effect of Lipton is as a result the large ECF volume created by the water content and more importantly the xanthine content of the caffeine which increases the urine output (Kadam et al,2007) by causing vasodilatation of renal vessels thus increasing glomerular filtration rate(Sembulingam and Sebulimgam,2006).

The difference in onset of diuretic effect of Lipton tea between male and female is not clear. However, it is possible that there may be differences in sensitivity of renal system between male and female human subjects to xanthine.

The mean urine output for period of experiment which was $2 \mathrm{hrs} 30 \mathrm{mins}$ (150mins) was more in Group B (water) followed by Group E (Lipton tea).

A higher volume was seen in female than that of male subjects in Groups B (water),C ( $0.9 \%$ Saline) and D (1\% Saline) but the difference were however not significant. In the Control group, a higher volume was observed in male, This may be due to higher body water in male when compared to that of the female (Ellison, 2005)

The result of urine $\mathrm{pH}$ (Table 2) of the different groups showed a decrease in urine $\mathrm{pH}$ with increase in time over period of experiment in both male and female human subject, the observed decrease was however not significant. The urine $\mathrm{pH}$ was within normal range of urine $\mathrm{pH}$ (4.5-8.0) (Guyton, 2006).

\section{Conclusion}

In conclusion, water and Lipton tea produced higher urine volume (diuresis) with water having the maximum urine volume in this experiment. Saline load had no diuretic effect especially the Normal saline solution. Hypertonic saline solution however showed tendency of increased urine volume in both male and female human subjects. This implies that the physiological response in regulating urine output is the same in the male and female human subjects to the volume loading though there may be variations in the pattern of response to the regulatory factors as seen in respect to time between male and female human subjects.

\section{References}

[1] Arthur C. Guyton and John E. Hall. Textbook of Medical Physiology. Eleventh Edition. Pg 291-363, 2006 ISBN 0-7216-0240-1

[2] David H. Ellison Disorders of sodium balance. Chapter1 2005 Vol. 1 Atlas of disease of the kidney.www.kidneyatlas.org/toc.htm

[3] Kadam S.S., Maadik K.R., Bothara K. G Principle of Medicinal Chemistry-2007Vol 1 diuretics pg.218,Nirali Prakashan Publicaion.

[4] Linda S.Costanzo,Textbook of Physiology. Third Edition2007. Pg235-295

[5] Paudel B H, Kumer S. Effect of water and saline load on urinary output in healthy undergraduate medical students. Journal of Nepal Medical Association 432003;23-26

[6] Poujeol P, Chabardes D, Roinel N, De Rouffignac C Influence of extracellular fluid volume expansion on magnesium, calcium and phosphate handling along the rat nephron. Pflugers Arch 1976; 3651976 (2-3): 203-211.

[7] Sembulingam K. and Prema Sembulingam, Essentials of Physiology Fourth Edition 2006ISBN 81-8061-826-9

[8] Udokong N. E. and Akpogromeh B.A. Effect of volume loading with water,Normal Saline,palmwine and Lipton tea on urinary output, pH, Specific Gravity, sodium and Potassium Concentration in Human Subjects. Nigerian Journal of Physiological Sciences $202005(1-2) 101-106$ 